\title{
Osmotic Adjustment Associated with Variation in Bentgrass Tolerance to Drought Stress
}

\author{
Michelle DaCosta and Bingru Huang1 \\ Department of Plant Biology and Pathology, Rutgers University, New Brunswick, NJ 08901
}

AdDitional INDEX wORDs. Agrostis, creeping bentgrass, velvet bentgrass, water soluble carbohydrates, proline, inorganic ions

\begin{abstract}
Osmotic adjustment (OA) is a major physiological mechanism associated with maintenance of cell turgor in response to dehydration stress. The objectives of this study were to examine changes in capacity for OA in relation to plant tolerance to drought stress for two cool-season turfgrass species, creeping bentgrass (Agrostis stolonifera $\mathrm{L}$.) and velvet bentgrass (A. canina $\mathrm{L}$.), and to determine major solutes contributing to OA in these grass species. Plants of 'L-93' creeping bentgrass and 'Greenwich' velvet bentgrass were grown in a growth chamber in polyvinyl chloride (PVC) tubes $(5 \mathrm{~cm}$ diameter, $40 \mathrm{~cm}$ high) filled with a 1:3 (v/v) sterilized mixture of sand and sandy loam soil. The experiment consisted of two soil moisture treatments: 1) well-watered control, irrigated three times per week to maintain soil moisture near pot capacity; and 2) drought stress, irrigation completely withheld. Velvet bentgrass exhibited higher drought tolerance compared to creeping bentgrass, as manifested by higher visual turfgrass quality (TQ) and leaf relative water content (RWC) under drought stress. Both creeping bentgrass and velvet bentgrass exhibited OA in response to drought stress; however, velvet bentgrass exhibited $50 \%$ to $60 \%$ higher magnitude of $\mathrm{OA}$, which could be related to the maintenance of higher leaf RWC and TQ for greater drought duration compared to creeping bentgrass. $O A$ for both creeping bentgrass and velvet bentgrass was associated with accumulation of water soluble carbohydrates during the early period of drought and increases in proline content following prolonged period of drought; however, inorganic ion content $\left(\mathrm{Ca}^{2+}\right.$ and $\left.\mathrm{K}^{+}\right)$did not considerably change under drought stress and did not seem to contribute to $\mathrm{OA}$ in these species.
\end{abstract}

The maintenance of favorable water status is critical for plant survival in dry environments. The accumulation of nontoxic, compatible solutes within plant cells [i.e., osmotic adjustment $(\mathrm{OA})]$ is a major trait associated with maintenance of high cell turgor potential and water retention in response to dehydration stress (Bohnert and Jensen, 1996; Hare et al., 1998; Ingram and Bartels, 1996). Osmotically active solutes involved in OAinclude amino acids (e.g., proline), ammonium compounds (e.g., glycine betaine), sugars (e.g., fructans, sucrose), polyols (e.g., mannitol), inorganic ions (e.g., potassium), and organic acids (e.g., malate) (Chaves et al., 2003; Zhang et al., 1999). OA-induced turgor maintenance supports the continuance of cell elongation under water deficit. Furthermore, plants that exhibit OA may experience loss in turgor at lower water potentials than in nonosmotically adjusted plants (Zhang et al., 1999). In addition to turgor maintenance, the accumulation of these solutes has also been associated with the maintenance of membrane and protein structures, protection against oxidative damage, and thus higher structural stabilization under water deficit (Arakawa, 1991; Crowe et al., 1992; Hoekstra et al., 2001; Rhodes and Hanson, 1993).

Generally, OA is considered a drought tolerance mechanism, since plant metabolic and physiological functions may be sustained at low water potentials; however, OA may also contribute to drought avoidance due its association with enhanced root growth and soil water extraction under drought conditions (Nguyen-Queyrens and Bouchet-Lannat, 2003). Leaf OA has been positively correlated with drought tolerance of various species, including turfgrasses (Qian and Fry, 1997; White et al., 1992), forage grasses (Geerts et al., 1998; Wilson and Ludlow, 1983), and cereal grasses

Received for publication 13 Dec. 2005. Accepted for publication 24 Feb. 2006. The authors wish to thank Dr. Shimon Rachmilevitch and Emily Merewitz for critical review and suggestions on the manuscript. Partial funding for this study was provided by the Rutgers Univ. Center for Turfgrass Science.

1To whom reprint requests should be addressed. Email address: huang@aesop. rutgers.edu
(Morgan, 1983; Premachandra et al., 1995). The extent of OA was higher in drought-tolerant cultivars of durum wheat(Triticum durum Desf.) compared to the drought-sensitive cultivar that exhibited more rapid declines in leaf turgor pressure (Bajji et al., 2001). Qian and Fry (1997) reported that better drought tolerance for buffalograss [Bouteloua dactyloides (Nutt.) Columbus] and zoysiagrass (Zoysia japonica Steud.) was associated with higher magnitude of OA compared to tall fescue (Festuca arundinacea Shreb.) under soil drying conditions. In addition to contributing to shoot turgor maintenance and water retention during drought stress, OA also contributes to recovery from drought stress (Chaves et al., 2003). Elmi and West (1995) suggested that OA-enhanced turgor maintenance increased the viability of meristematic and leaf elongation regions in tall fescue, which was a critical factor for survival and recovery after drought.

Limited irrigation or rainfall often result in severe turf quality declines; therefore, utilizing species with improved tolerance to drought stress is an important strategy for turfgrass management in water-limiting environments. Despite the importance of osmotic regulation of drought tolerance in plants, limited research has been done on genetic variability in OA of cool-season, $\mathrm{C}_{3}$ turfgrass species in response to drought stress. Drought responses and cool-season species variation in the degree of OA are not well understood. Furthermore, the major solutes contributing to $\mathrm{OA}$ in cool-season turfgrasses in general have not been well documented. Greater insight into osmotic relations in drought tolerance of turfgrass species would be useful for improving selection criteria and management strategies for grass growth in water-limiting environments. The objectives of this study were to examine genetic variation and changes in capacity for $\mathrm{OA}$ in response to drought stress for two cool-season turfgrass species, creeping bentgrass and velvet bentgrass, and to determine major solutes contributing to OA in bentgrass species. Our previous investigation in a field study found that velvet bentgrass was more drought tolerant than creeping bentgrass (DaCosta and Huang, 2006). 


\section{Materials and Methods}

Plant materials and growing conditions. Sods of 'L-93' creeping bentgrass and 'Greenwich' velvet bentgrass were collected from 2-year-old field plots at the Rutgers Turfgrass Horticulture Farm II in North Brunswick, N.J. Plants were washed free of soil and transplanted into polyvinyl chloride (PVC) tubes (5 cm diameter, $40 \mathrm{~cm}$ height) filled with a 1:3 (v/v) sterilized mixture of sand and sandy loam soil (fine-loamy, mixed, mesic, Typic Hapludult). A nylon screen covered the bottom of each PVC tube in order to contain the soil and allow for drainage of water from the tubes.

Plants were grown in a greenhouse under natural light conditions and $25^{\circ} \mathrm{C}$ day $/ 15^{\circ} \mathrm{C}$ night temperatures for $\approx 50 \mathrm{~d}$ to allow for establishment of turf canopy and root systems. Plants were watered three times per week until water ran freely from the bottoms of the tubes. All plants were hand clipped weekly at $\approx 3$ - to 4-cm height and fertilized every $14 \mathrm{~d}$ with full-strength Hoagland's solution (Hoagland and Arnon, 1950) to provide nutrients and facilitate plant establishment prior to initiation of treatments. Plants were then transferred to a growth chamber set at $20^{\circ} \mathrm{C}$ day $/ 15^{\circ} \mathrm{C}$ night temperatures, $14 \mathrm{~h}$ of photoperiod, and photosynthetic photon flux density of $600 \mu \mathrm{mol} \cdot \mathrm{m}^{-2} \cdot \mathrm{s}^{-1}$ and allowed to acclimate for $15 \mathrm{~d}$ before treatments were imposed.

Treatments. The experiment consisted of two soil moisture treatments: 1) well-watered control, irrigated three times per week with tap water to maintain soil moisture near pot capacity $(\approx 30 \%, v / v)$; and 2) drought stress, irrigation completely withheld. The treatments were terminated after $18 \mathrm{~d}$, when the plants under drought treatment were desiccated and brown, which corresponded with soil moisture content of $\approx 6 \%(\mathrm{v} / \mathrm{v})$.

Measurements. Turf quality was rated visually based on turfgrass color (extent of chlorosis and leaf senescence), plant density, and degree of leaf wilting on a 1-9 scale $(1=$ brown, senesced, and desiccated turf and $9=$ fully turgid, green, and dense turf). A rating of 6 indicated the minimum acceptable turf quality based on these parameters.

Volumetric soil water content at the 0 - to 8 -cm soil depth was measured using the time-domain reflectometry (TDR) method (Topp et al., 1980) using three-pronged waveguides installed vertically in the 0- to 8-cm soil layer (Soil Moisture Equipment, Santa Barbara, Calif.).

Single-leaf net photosynthetic rate (Pn) was measured on four to five fully-expanded leaves per pot using a portable gas exchange system (LI-6400; LI-COR, Lincoln, Nebr.). Individual leaves attached to the plant were placed within a $6-\mathrm{cm}^{2}$ leaf chamber and allowed to equilibrate for $\approx 1 \mathrm{~min}$ at $P A R$ of $600 \mu \mathrm{mol} \cdot \mathrm{m}^{-2} \cdot \mathrm{s}^{-1}$ and $400 \mu \mathrm{L} \cdot \mathrm{L}^{-1} \mathrm{CO}_{2}$ before data were recorded. Total leaf area was then measured to calculate Pn expressed as uptake of $\mathrm{CO}_{2}$ in $\mu \mathrm{mol} \cdot \mathrm{m}^{-2} \cdot \mathrm{s}^{-1}$.

Leaf relative water content was determined weekly using 10-15 fully expanded leaves per pot according to Barrs and Weatherley (1962). Leaf samples were detached from the plants and immediately weighed to determine fresh weight (FW). Samples were placed into covered petri dishes filled with water for leaves to reach full hydration. After approximately $18 \mathrm{~h}$ at $4^{\circ} \mathrm{C}$, leaf samples were blotted dry with paper towels, and then weighed immediately to determine turgid weight (TW). Leaf tissue was then dried in an oven at $75^{\circ} \mathrm{C}$ for $72 \mathrm{~h}$ to determine dry weight (DW). Leaf RWC was calculated as: $(\mathrm{FW}-\mathrm{DW}) /(\mathrm{TW}-\mathrm{DW}) \times 100$.

Osmotic adjustment was determined according to the rehydration method, whereby osmotic potential of leaves at full turgor was determined after leaves (stressed and nonstressed) were soaked in water for full rehydration (Blum, 1989; Blum and Sullivan, 1986). Turgid leaf samples were frozen in liquid nitrogen and subsequently stored at $-20{ }^{\circ} \mathrm{C}$ until analysis of leaf osmotic potential. Frozen tissue samples were thawed and cell sap was pressed from leaves, which was subsequently analyzed for osmolarity (c) $\left(\mathrm{mmol} \cdot \mathrm{kg}^{-1}\right)$ using a vapor pressure osmometer (Vapro model 5520; Wescor, Logan, Utah). Osmolarity of cell sap was converted from mmol $\mathrm{kg}^{-1}$ to osmotic potential (MPa) using the formula: $\mathrm{MPa}=-\mathrm{c} \times 2.58 \times 10^{-3}$. Osmotic adjustment was calculated as the difference between osmotic potential of stressed leaves at full turgor from osmotic potential of nonstressed leaves at full turgor according to Blum (1989) and Blum and Sullivan (1986).

Organic and inorganic solutes were extracted from leaves sampled on the same day as RWC and OA using the method previously described by Lerner et al. (1978) and modified by Lacerda et al. (2003). Briefly, $300 \mathrm{mg}$ of fresh leaves were cut into 1 - to $2-\mathrm{cm}$ segments and placed in test tubes containing 15 $\mathrm{mL}$ of $0.5 \%$ toluene solution. Samples were placed in a $30^{\circ} \mathrm{C}$ water bath shaker for $1 \mathrm{~h}$ and then filtered into graduated test tubes. The extraction was repeated for a total of three times with the same leaf tissue and then final volume was adjusted to $50 \mathrm{~mL}$ with deionized water. The pooled extract was used to determine the content of water soluble carbohydrates (WSC), proline, and inorganic ions.

WSC content was determined using the method of Buysse and Merckx (1993) with modifications. Briefly, $1 \mathrm{~mL}$ of extracted solution was added to $1 \mathrm{~mL}$ of $18 \%$ phenol. From a fast-flowing pipette, $5 \mathrm{~mL}$ of concentrated sulfuric acid was added to the phenol-extract solution, and thoroughly mixed using a vortex mixer. After $\approx 15$ min, test tubes were vortexed again and placed in a 30 ${ }^{\circ} \mathrm{C}$ water bath for $20 \mathrm{~min}$. Absorbance of the solution was measured at $490 \mathrm{~nm}$ and WSC content was determined by reference to a standard curve and calculated on a dry weight basis.

Proline content was determined using the method described by Bates (1973). Briefly, $2 \mathrm{~mL}$ of extracted solution was added to $2 \mathrm{~mL}$ of acid-ninhydrin and $2 \mathrm{~mL}$ of glacial acetic acid. The mixture was heated at $100{ }^{\circ} \mathrm{C}$ in a water bath for $1 \mathrm{~h}$, and the reaction was then terminated in an ice bath. Subsequently, $4 \mathrm{~mL}$ of toluene was added to each tube and vortexed for $30 \mathrm{~s}$. After phase separation, the proline-ninhydrin chromophore in the upper phase was used to measure absorbance at $520 \mathrm{~nm}$. Proline concentration was determined by reference to a standard curve and calculated on a dry weight basis.

The concentrations of inorganic ions, $\mathrm{Ca}^{2+}$ and $\mathrm{K}^{+}$, were analyzed using a 1:50 (v/v) dilution of cell sap with an inductively coupled plasma spectrophotometer (ICP) (Fisons Instruments, Beverly Mass.). $\mathrm{Ca}^{2+}$ and $\mathrm{K}^{+}$were analyzed due to their regulation of guard cell turgor and stomatal aperture.

At the end of the experiment, roots were washed free of soil and separated into upper $(0-20 \mathrm{~cm})$ and lower $(20-40 \mathrm{~cm})$ root sections. Roots were then dried in an oven at $75^{\circ} \mathrm{C}$ for determination of root dry weight.

EXPERIMENTAL DESIGN AND STATISTICAL ANALYSIS. The experiment was a completely randomized design with four replicates for a total of 16 plants. Effects of water treatment, species, and corresponding interactions were determined by analysis of variance according to the general linear model procedure of SAS (version 8.2; SAS Institute, Cary, N.C.). Differences between treatment means were separated by the least significant difference (LSD) test at the 0.05 probability level. 


\section{Results}

TQ significantly declined with drought duration for both creeping bentgrass and velvet bentgrass (Fig. 1). TQ for creeping bentgrass declined to 6.5 by $7 \mathrm{~d}$ of treatment, which was significantly less than TQ of well-watered control plants (9.0). TQ for velvet bentgrass declined to levels below that of control plants by $11 \mathrm{~d}$ of treatment. After $14 \mathrm{~d}$ of drought treatment, TQ for creeping bentgrass and velvet bentgrass fell to below the minimum acceptable quality level(6.0) (3.3 and 4.8, respectively). By the end of drought period (18 d), TQ for creeping bentgrass and velvet bentgrass plants was 1.6 and 3.7, respectively. When comparing the species, velvet bentgrass had higher $(P \leq 0.05)$ TQ compared to creeping bentgrass at 7,14, and $18 \mathrm{~d}$ of drought treatment.

Soil moisture at the 0 - to $8-\mathrm{cm}$ soil depth was maintained at $\approx 27 \%$ and $31 \%$ for well-watered plants of creeping bentgrass and velvet bentgrass, respectively, throughout the experimental period (Fig. 2). By $5 \mathrm{~d}$ of drought treatment, soil moisture content in the upper soil layer declined from 28 to $11 \%$ for creeping bentgrass and from $29 \%$ to $15 \%$ for velvet bentgrass. By $12 \mathrm{~d}$ of drought stress, soil moisture at 0 - to $8-\mathrm{cm}$ soil depth had declined to $7 \%$ and $6 \%$ for creeping bentgrass and velvet bentgrass, respectively.

Well-watered plants of creeping bentgrass and velvet bentgrass maintained Pn levels at $\approx 2.7$ and $3.3 \mu \mathrm{mol} \cdot \mathrm{m}^{-2} \cdot \mathrm{s}^{-1} \mathrm{CO}_{2}$, respectively, throughout the experimental period (Fig. 3). Rapid declines in single-leaf Pn were observed for drought-stressed plants of both species within the first $5 \mathrm{~d}$ of treatment. Pn declined by $\approx 70 \%$ at $5 \mathrm{~d}$ of drought treatment for both species, and generally remained at these levels for the remainder of the drought treatment.

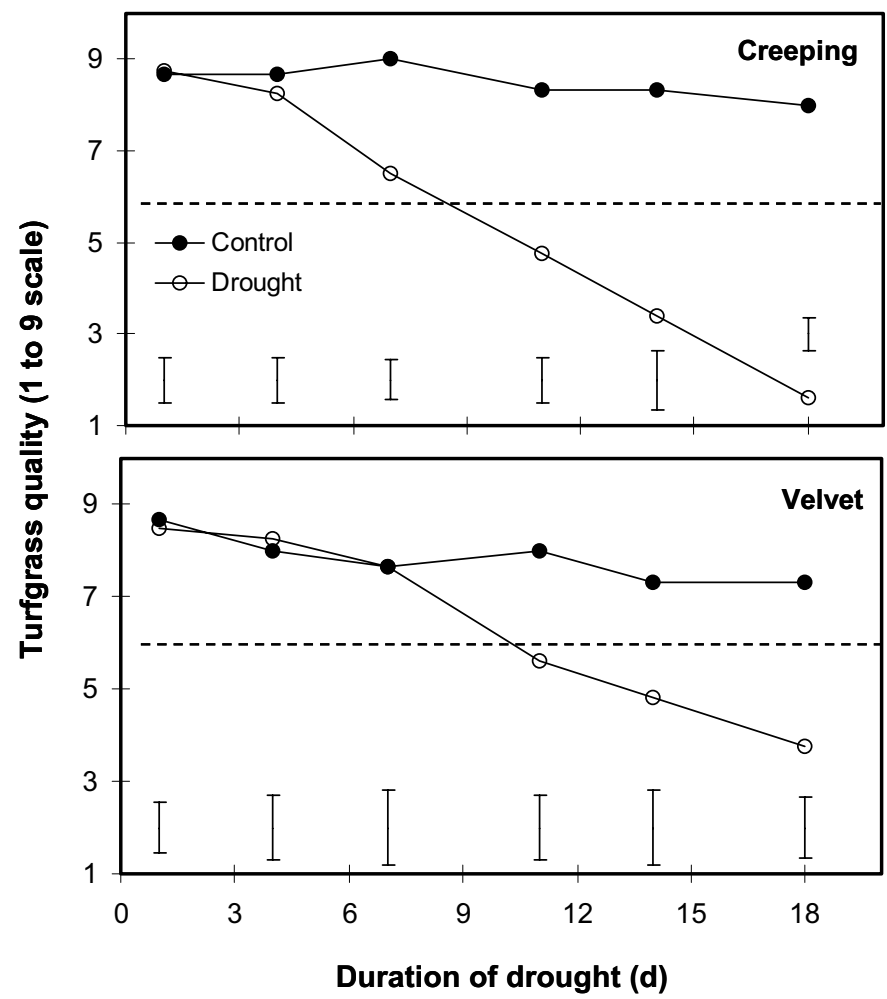

Fig. 1. Changes in turfgrass quality (TQ) during drought stress for creeping bentgrass and velvet bentgrass. A value of "9" represents the best quality (green, dense canopy) and " 1 " represents the lowest quality (brown, desiccated). The dashed line represents the minimal acceptable TQ (6). Vertical bars are LSD values $(P \leq 0.05)$ indicating statistically significant differences for treatment comparisons at a given day of treatment.

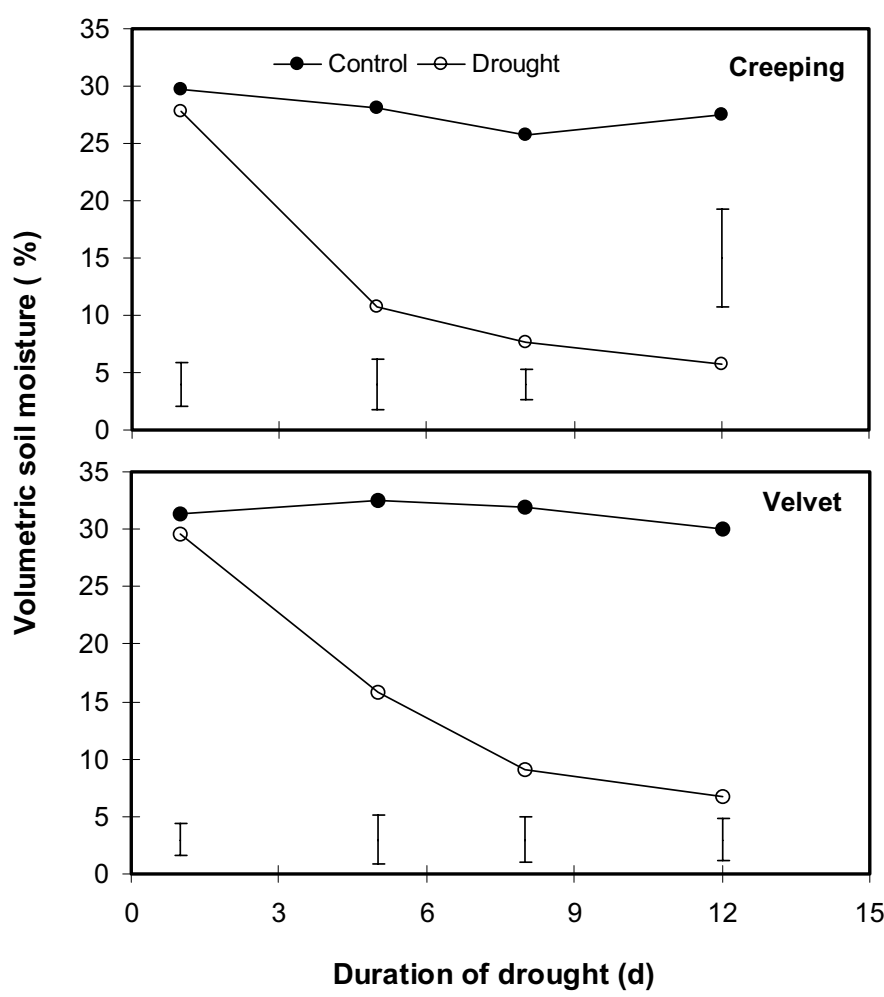

Fig. 2. Changes in soil moisture content at the 0 to $8-\mathrm{cm}$ soil depth during drought stress for creeping bentgrass and velvet bentgrass. Vertical bars are LSD values $(P$ $\leq 0.05$ ) indicating statistically significant differences for treatment comparisons at a given day of treatment.

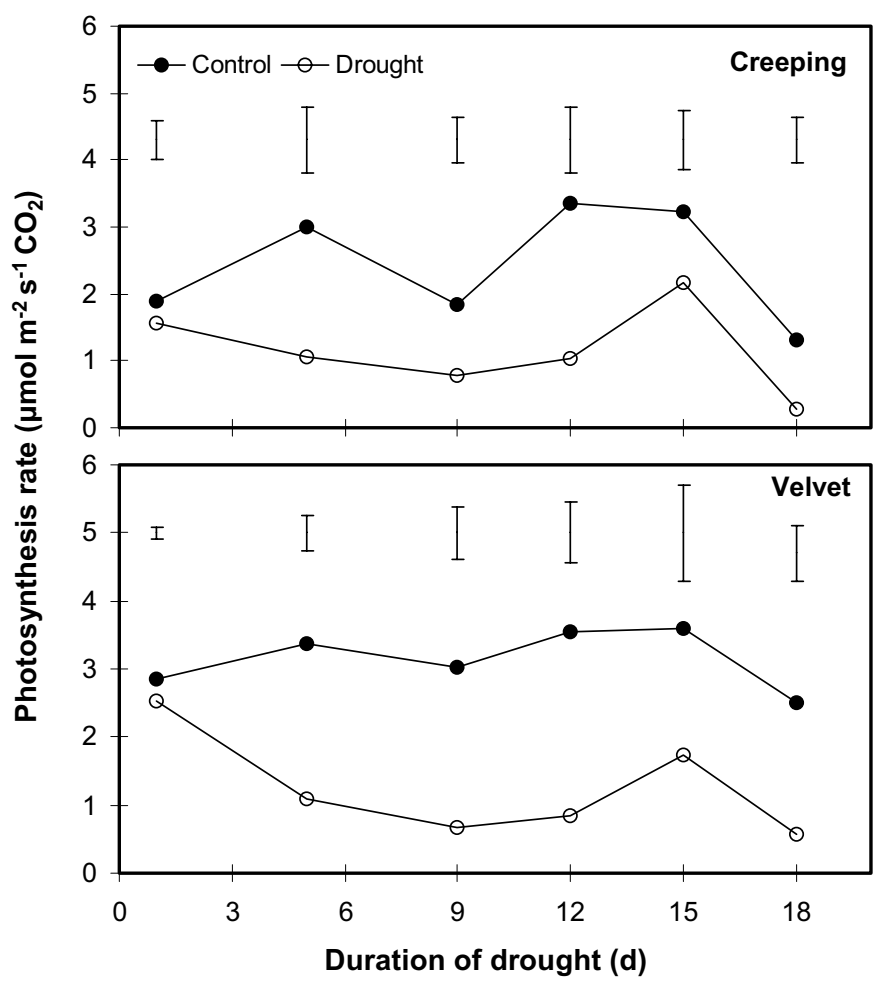

Fig. 3. Changes in single-leaf net photosynthetic rate during drought stress for creeping bentgrass and velvet bentgrass. Vertical bars are LSD values $(P \leq 0.05)$ indicating statistically significant differences for treatment comparisons at a given day of treatment. 
Well-watered plants of both creeping bentgrass and velvet bentgrass generally maintained leaf RWC around 95\% (Fig. 4). For the first $8 \mathrm{~d}$ of drought treatment, no significant differences were detected in RWC among the drought and well-watered treatments for both species. By $12 \mathrm{~d}$ of drought treatment, RWC for creeping bentgrass significantly declined compared to that of well-watered plants; however, no significant differences in RWC were observed between well-watered and drought-stressed plants for velvet bentgrass. By $15 \mathrm{~d}$ of drought, RWC declined to $68 \%$ for creeping bentgrass and $75 \%$ for velvet bentgrass.

Drought stress resulted in increased OA for both creeping bentgrass and velvet bentgrass from 8 to $15 \mathrm{~d}(P \leq 0.05)$ (Table 1$)$. OA was significantly higher in drought-stressed plants of creeping bentgrass $(0.15,0.18$, and $0.27 \mathrm{MPa})$ and velvet bentgrass $(0.32$, 0.48 , and $0.53 \mathrm{MPa}$ ) compared to control plants at 8,12 , and 15 $\mathrm{d}$ of treatment, respectively. In comparing the two species, velvet bentgrass exhibited $53 \%, 63 \%$, and $49 \%$ greater OA than creeping bentgrass at 8,12 , and $15 \mathrm{~d}$ of drought treatment, respectively.

WSC increased by $11 \%$ and $13 \%$ in drought-stressed plants of creeping bentgrass and velvet bentgrass, respectively, compared to well-watered controls at $8 \mathrm{~d}$ of treatment (Table 2). At this time, velvet bentgrass exhibited higher levels of WSC compared to creeping bentgrass, regardless of treatment. By $15 \mathrm{~d}$ of drought, WSC content in drought-stressed plants were $19 \%$ and $17 \%$ higher for creeping bentgrass and velvet bentgrass, respectively, than well-watered controls. There were no significant differences in WSC content between creeping bentgrass and velvet bentgrass at this duration of drought, regardless of treatment.

At $8 \mathrm{~d}$ of drought treatment, proline content did not differ between drought-stressed and well-watered plants for either creeping bentgrass or velvet bentgrass (Table 2). By $15 \mathrm{~d}$ of drought, proline content was $92 \%$ and $86 \%$ higher in drought-stressed plants of creeping bentgrass and velvet bentgrass, respectively, compared to well-watered controls. There were no significant differences in proline content between drought-stressed creeping bentgrass and velvet bentgrass at 8 and $15 \mathrm{~d}$ of treatment.

There were no significant differences in $\mathrm{Ca}^{2+}$ and $\mathrm{K}^{+}$ion content between drought-stressed and well-watered plants of both creeping bentgrass and velvet bentgrass at $8 \mathrm{~d}$ of treatment (Table 2). At $15 \mathrm{~d}$ of treatment, drought-stressed creeping bentgrass exhibited higher $\mathrm{K}^{+}$content than control plants ( 33.73 vs. $24.77 \mathrm{mg} \cdot \mathrm{g}^{-1} \mathrm{DW}$ for drought and control plants, respectively). In general, there were no differences in $\mathrm{Ca}^{2+}$ ion content between creeping bentgrass and velvet bentgrass, regardless of treatment or treatment duration. Control and drought-stressed plants of creeping bentgrass exhibited approximately $30 \%$ higher $\mathrm{K}^{+}$content than velvet bentgrass at $8 \mathrm{~d}$ of treatment. After $15 \mathrm{~d}$, drought-stressed plants of creeping bentgrass had higher $\mathrm{K}^{+}$content $\left(33.73 \mathrm{mg} \cdot \mathrm{g}^{-1} \mathrm{DW}\right)$ than well-watered creeping bentgrass plants $\left(24.77 \mathrm{mg} \cdot \mathrm{g}^{-1} \mathrm{DW}\right)$ and drought-stressed velvet bentgrass $\left(26.41 \mathrm{mg} \cdot \mathrm{g}^{-1} \mathrm{DW}\right)$.

Drought stress reduced root dry weight in the $0-$ to $20-\mathrm{cm}$ soil layer by $46 \%$ and $36 \%$ for creeping bentgrass and velvet bentgrass, respectively (Table 3 ). There was a $46 \%$ reduction in root dry weight in the 20 - to $40-\mathrm{cm}$ soil layer for droughtstressed creeping bentgrass; however, there were no differences in root dry weight in this soil layer between well-watered and drought-stressed plants of velvet bentgrass. In general, creeping bentgrass had greater total root mass at the $0-$ to $20-\mathrm{cm}$ and $20-$ to $40-\mathrm{cm}$ soil layers compared to velvet bentgrass under well-watered conditions. Under drought stress, however, there were no differences in root dry weight between the two species regardless of soil depth.

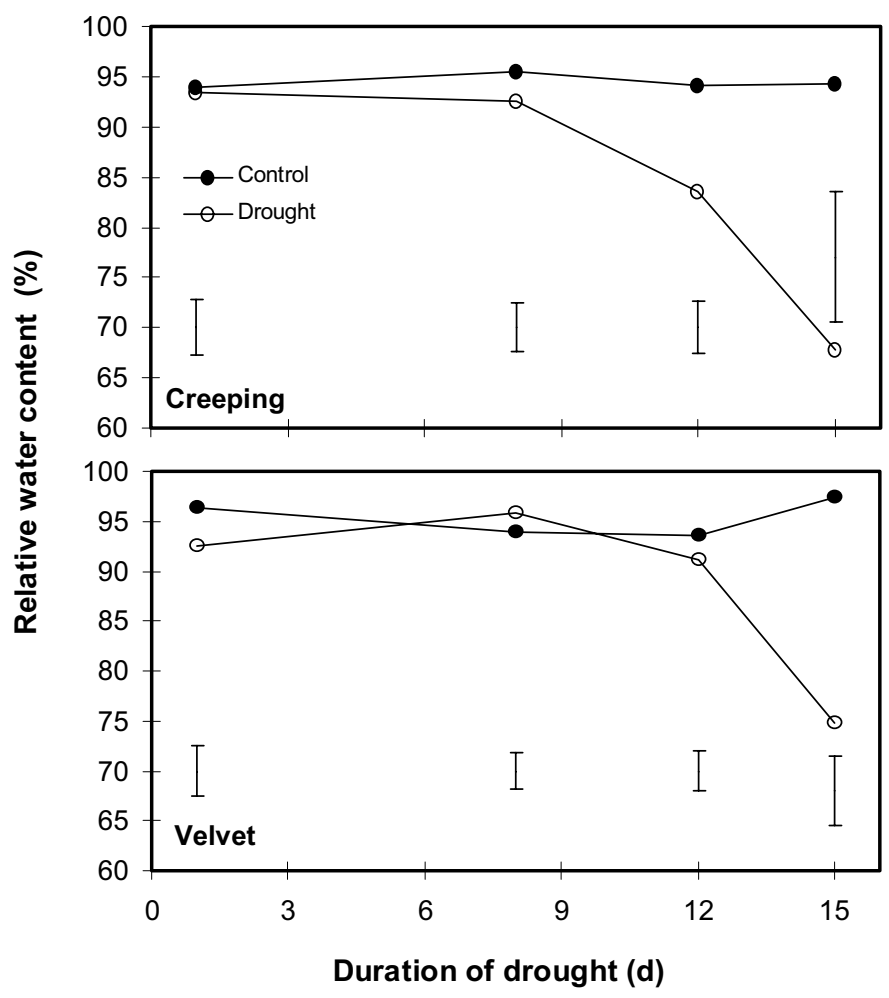

Fig. 4. Changes in leaf relative water content during drought stress for creeping bentgrass and velvet bentgrass. Vertical bars are LSD values $(P \leq 0.05)$ indicating statistically significant differences for treatment comparisons at a given day of treatment.

Table 1. Osmotic adjustment (OA) for creeping bentgrass and velvet bentgrass at 8,12 , and $15 \mathrm{~d}$ of drought treatment. Values followed by the same lowercase letter within a column for each species indicate no significant differences in OA between well-watered controls and drought-stressed plants $(P \geq 0.05)$ based on an LSD test. Values followed by the same uppercase letter indicate no significant differences in $\mathrm{OA}$ between creeping bentgrass and velvet bentgrass $(P \geq 0.05)$ for a given treatment based on an LSD test.

\begin{tabular}{llccc}
\hline Bentgrass & & \multicolumn{3}{c}{ Osmotic adjustment $(\mathrm{MPa})$} \\
\cline { 3 - 5 } species & Treatment & $8 \mathrm{~d}$ & $12 \mathrm{~d}$ & $15 \mathrm{~d}$ \\
\hline Creeping & Control & $0.03 \mathrm{~b} \mathrm{~A}$ & $0.02 \mathrm{~b} \mathrm{~A}$ & $0.03 \mathrm{~b} \mathrm{~A}$ \\
& Drought & $0.15 \mathrm{a} \mathrm{B}$ & $0.18 \mathrm{a} \mathrm{B}$ & $0.27 \mathrm{a} \mathrm{B}$ \\
\multirow{2}{*}{ Velvet } & Control & $0.06 \mathrm{~b} \mathrm{~A}$ & $0.06 \mathrm{~b} \mathrm{~A}$ & $0.02 \mathrm{~b} \mathrm{~A}$ \\
& Drought & $0.32 \mathrm{a} \mathrm{A}$ & $0.48 \mathrm{a} \mathrm{A}$ & $0.53 \mathrm{a} \mathrm{A}$ \\
\hline
\end{tabular}

\section{Discussion}

Withholding irrigation from creeping bentgrass and velvet bentgrass plants resulted in declines in TQ, leaf RWC, and leaf Pn rates, with the time and severity of decline varying with species. Velvet bentgrass exhibited higher drought tolerance compared to creeping bentgrass, as manifested by delayed and less severe reduction in TQ and leaf RWC, which is consistent with our previous observations under field conditions (DaCosta and Huang, 2006). Single leaf Pn rates also decreased during drought to a similar extent between creeping bentgrass and velvet bentgrass, and therefore did not seem to account for species differences in drought tolerance. Prolonged leaf turgidity in velvet bentgrass could be associated with a mechanism contributing to leaf water retention.

Both cool-season grass species exhibited OA in response to drought stress. However, velvet bentgrass exhibited 50\% to $60 \%$ 
Table 2. Changes in water soluble carbohydrates (WSC), proline, and inorganic ions for creeping bentgrass and velvet bentgrass at 8 and $15 \mathrm{~d}$ of drought treatment. Values followed by the same lowercase letter within a column for each species indicate no significant differences in solute accumulation between wellwatered controls and drought-stressed plants $(P \geq 0.05)$ based on an LSD test. Values followed by the same uppercase letter indicate no significant differences in solute accumulation between creeping bentgrass and velvet bentgrass $(P \geq 0.05)$ for a given treatment based on an LSD test.

\begin{tabular}{|c|c|c|c|c|c|}
\hline \multirow[b]{2}{*}{$\begin{array}{l}\text { Bentgrass } \\
\text { species }\end{array}$} & \multirow[b]{2}{*}{ Treatment } & \multicolumn{4}{|c|}{ Organic and inorganic solutes } \\
\hline & & $\begin{array}{c}\mathrm{WSC} \\
\left(\mu \mathrm{g} \cdot \mathrm{g}^{-1} \mathrm{DW}\right)\end{array}$ & $\begin{array}{c}\text { Proline } \\
\left(\mu \mathrm{mol} \cdot \mathrm{g}^{-1} \mathrm{DW}\right)\end{array}$ & $\begin{array}{c}\mathrm{Ca}^{2+} \\
\left(\mathrm{mg} \cdot \mathrm{g}^{-1} \mathrm{DW}\right)\end{array}$ & $\begin{array}{c}\mathrm{K}^{+} \\
\left(\mathrm{mg} \cdot \mathrm{g}^{-1} \mathrm{DW}\right)\end{array}$ \\
\hline Creeping & $\begin{array}{l}\text { Control } \\
\text { Drought }\end{array}$ & $\begin{array}{l}159.1 \text { b B } \\
178.4 \text { a B }\end{array}$ & $\begin{array}{r}7.1 \mathrm{a} \mathrm{A} \\
12.9 \mathrm{a} \mathrm{A}\end{array}$ & $\begin{array}{l}6.12 \mathrm{a} A \\
6.29 \mathrm{aA}\end{array}$ & $\begin{array}{l}44.42 \text { a A } \\
40.68 \text { a A }\end{array}$ \\
\hline Velvet & $\begin{array}{l}\text { Control } \\
\text { Drought }\end{array}$ & $\begin{array}{l}186.2 \mathrm{~b} \mathrm{~A} \\
214.1 \mathrm{a} \mathrm{A}\end{array}$ & $\begin{array}{l}11.8 \text { a A } \\
17.6 \text { a A }\end{array}$ & $\begin{array}{l}7.01 \mathrm{aA} \\
6.50 \mathrm{aA}\end{array}$ & $\begin{array}{l}27.02 \text { a B } \\
31.53 \text { a B }\end{array}$ \\
\hline Creeping & $\begin{array}{l}\text { Control } \\
\text { Drought }\end{array}$ & $\begin{array}{l}146.7 \mathrm{~b} \mathrm{~A} \\
180.5 \mathrm{a} \mathrm{A}\end{array}$ & $\begin{array}{r}6.3 \mathrm{~b} \mathrm{~A} \\
82.6 \mathrm{a} \mathrm{A}\end{array}$ & $\begin{array}{l}3.56 \text { a } \mathrm{A} \\
4.59 \text { a A }\end{array}$ & $\begin{array}{l}24.77 \mathrm{~b} \mathrm{~A} \\
33.73 \mathrm{a} \mathrm{A}\end{array}$ \\
\hline Velvet & $\begin{array}{l}\text { Control } \\
\text { Drought }\end{array}$ & $\begin{array}{l}164.7 \mathrm{~b} \mathrm{~A} \\
198.0 \mathrm{a} \mathrm{A}\end{array}$ & $\begin{array}{l}13.1 \mathrm{~b} \mathrm{~A} \\
95.1 \mathrm{a} \mathrm{A}\end{array}$ & $\begin{array}{l}4.55 \mathrm{aA} \\
5.03 \mathrm{aA}\end{array}$ & $\begin{array}{l}29.09 \text { a A } \\
26.41 \text { a B }\end{array}$ \\
\hline
\end{tabular}

Table 3. Root biomass at the end of the experimental period for creeping bentgrass and velvet bentgrass. Data presented are for average root dry weights at the 0 - to 20 -cm and 20 - to 40 -cm soil depths. Values followed by the same lowercase letter within a column for each species indicate no significant differences in root dry weight between well-watered controls and drought-stressed plants $(P \geq 0.05)$ based on an LSD test. Values followed by the same uppercase letter indicate no significant differences in root dry weight between creeping bentgrass and velvet bentgrass $(P \geq 0.05)$ for a given treatment based on an LSD test.

\begin{tabular}{lccc}
\hline Bentgrass & & \multicolumn{2}{c}{ Root dry wt $(\mathrm{g})$} \\
\cline { 3 - 4 } species & Treatment & $0-20 \mathrm{~cm}$ & $20-40 \mathrm{~cm}$ \\
\hline Creeping & Control & $1.07 \mathrm{a} \mathrm{A}$ & $0.57 \mathrm{a} \mathrm{A}$ \\
& Drought & $0.58 \mathrm{~b} \mathrm{~A}$ & $0.31 \mathrm{~b} \mathrm{~A}$ \\
Velvet & Control & $0.90 \mathrm{a} \mathrm{B}$ & $0.13 \mathrm{a} \mathrm{B}$ \\
& Drought & $0.58 \mathrm{~b} \mathrm{~A}$ & $0.18 \mathrm{a} \mathrm{A}$ \\
\hline
\end{tabular}

higher magnitude of OA compared to creeping bentgrass, which could be related to the maintenance of higher leaf RWC and TQ for greater drought duration compared to creeping bentgrass. The ability to adjust osmotically has been associated with enhanced drought tolerance in other species, either through maintenance of leaf and root growth during water deficit or enhanced survival of meristematic regions for improved recovery following drought (Elmi and West, 1995; Zhang et al., 1999). There is genetic diversity among different species and within cultivars of the same species in the capacity for OA (Babu et al., 1999; Morgan, 1992; Premachandra et al., 1992). Qian and Fry (1997) found that three warm-season grasses exhibited greater magnitude of OA (0.6 to $0.84 \mathrm{MPa}$ ) compared to OA of tall fescue $(0.34 \mathrm{MPa})$ under drought stress. Barker et al. (1993) also reported greater OA in warm-season ( 0.76 to $1.25 \mathrm{MPa}$ ) compared to cool-season grasses $(0.48$ to $0.68 \mathrm{MPa})$ in response to water deficit. The capacity of OA ranged from 0.15 to $0.53 \mathrm{MPa}$ for the two cool-season grass species in our study, depending on species and drought stress duration; however, it was within the range for other cool-season grass species (Barker et al., 1993; Qian and Fry, 1997).

It should be pointed out that the relationship between OA and stress tolerance also depends on rate of dehydration and stress severity (Maggio et al., 1997; Thomas, 1991). Under conditions of rapid dehydration, two forage grasses exhibited decreased OA compared to the same plants under a slower development of drought stress (Thomas, 1986), suggesting that gradual and uniform stress development was crucial for full expression of OA. Slower rates of water stress may allow for more gradual acclimation of physiological parameters such as photosynthesis and osmotic potential, whereas faster rates of dehydration mostly cause rapid cellular injury and thus result in the inability of plants to adjust osmotically before they are killed (Toft et al., 1987).

Organic and inorganic solutes that contribute to OA may also vary among different species and stress duration or severity. In annual and perennial grasses, some of the solutes associated with osmotic adjustment during drought and other environmental stresses include soluble sugars (Bajji et al., 2001; Barker, 1991; Richardson et al., 1992), inorganic ions (Jiang and Huang, 2001; Jones et al., 1980; Morgan, 1992), and proline (Bokhari and Trent, 1985; Marcum and Murdoch, 1994). In our study, WSC content significantly increased by $11 \%$ and $13 \%$ by $8 \mathrm{~d}$ of drought stress for creeping bentgrass and velvet bentgrass, respectively, compared to the well-watered controls. At this duration of drought stress, no significant changes were detected for proline and inorganic ion contents. Additionally, velvet bentgrass exhibited $\approx 15 \%$ greater WSC accumulation compared to creeping bentgrass. These results suggest that WSC were major osmotic solutes contributing to species variation and changes in OA during short-term (8 d) drought in bentgrasses. By $15 \mathrm{~d}$ of drought stress, the extent of WSC and proline accumulation among drought-stressed creeping bentgrass and velvet bentgrass plants was the same. When averaged across the two species, WSC and proline contents were $\approx 20 \%$ and $90 \%$ higher, respectively, compared to well-watered controls, which could be associated with increased OA under prolonged drought stress. Unlike WSC and proline content, there were generally no significant differences in $\mathrm{Ca}^{2+}$ and $\mathrm{K}^{+}$ ion content between drought-stressed and well-watered plants of both creeping bentgrass and velvet bentgrass, suggesting that $\mathrm{Ca}^{2+}$ and $\mathrm{K}^{+}$were not involved in OA for both bentgrass species exposed to drought stress. Soluble carbohydrates and proline could play a more important role for OA than inorganic ions in bentgrass adaptation to drought stress. 
In addition to OA, other morphological and/or physiological responses also serve important roles in drought stress tolerance. For example, plants exhibiting larger root systems could avoid dehydration by exploring water at deeper soil depths (Carrow, 1996; Qian et al., 1997), which would reduce the reliance on an OA mechanism for maintenance of plant water relations. Creeping bentgrass had a more extensive root system and more rapid soil moisture depletion, suggesting that it mainly adapted to drought through drought avoidance. However, for velvet bentgrass that had a less extensive root system, drought survival could largely rely on drought tolerance rather than avoidance mechanisms in order to maintain physiological and metabolic functions.

In summary, both creeping bentgrass and velvet bentgrass exhibited the capacity for OA that increased with duration of drought stress. However, velvet bentgrass exhibited higher TQ and leaf water relations compared to creeping bentgrass under drought stress. Improved water relations for velvet bentgrass under prolonged stress could be related to the greater capacity for OA of leaf tissue compared to creeping bentgrass. OA for both creeping bentgrass and velvet bentgrass was accompanied by the early accumulation of soluble carbohydrates, as well as proline in the latter stages of drought stress; inorganic ions did not greatly differ between well-watered and drought-stressed plants of either bentgrass species. Even though soluble carbohydrate accumulation was greater for velvet bentgrass during the early stages of drought stress, the similar accumulation of these compounds between the two species during the latter stages of drought stress suggest that additional osmotically active compounds may account for the differences in capacity for OA between creeping bentgrass and velvet bentgrass. Further investigation is necessary in order to determine the physiological mechanisms associated with greater OA capacity in velvet bentgrass.

\section{Literature Cited}

Arakawa, T. 1991. Protein-solvent interactions in pharmaceutical formulations. Pharmaceutical Res. 8:285-291.

Babu, R.C., M.S. Pathan, A. Blum, and N.T. Nguyen. 1999. Comparison of measurement methods of osmotic adjustment in rice cultivars. Crop Sci. 39:150-158.

Bajji, M., S. Lutts, and J.M. Kinet. 2001. Water deficit effects on solute contribution to osmotic adjustment as a function of leaf ageing in three durum wheat (Triticum durum Desf.) cultivars performing differently in arid conditions. Plant Sci. 160:669-681.

Barker, D.J. 1991. Physiological responses of sorghum and six forage grasses to water deficits. PhD Diss., Univ. of Nebr., Lincoln.

Barker, D.J., C.Y. Sullivan, and L.E. Moser. 1993. Water deficit effects on osmotic potential, cell wall elasticity, and proline in five forage grasses. Agron. J. 85:270-275.

Barrs, H.D. and P.E. Weatherley. 1962. A re-examination of the relative turgidity technique for estimating water deficit in leaves. Aust. J. Biol. Sci. 15:413-428.

Bates, L.S. 1973. Rapid determination of free proline for water-stress studies. Plant Soil 39:205-207.

Blum,A. 1989. Osmotic adjustment and growth of barley cultivars under drought stress. Crop Sci. 29:230-233.

Blum, A. and C.Y. Sullivan. 1986. The comparative drought resistance of landraces of sorghum and millet from dry and humid regions. Ann. Bot. (London) 57:835-846.

Bohnert, H.J. and R.G. Jensen. 1996. Strategies for engineering waterstress tolerance in plants. Trends Biotechnol. 14:89-97.

Bokhari, U.G. and J.D. Trent. 1985. Proline concentrations in water stressed grasses. J. Range Mgt. 38:37-38.
Buysse, J. and R. Merckx. 1993. Acclimation of potato plants to polyethylene glycol-induced water deficit: II. Contents and subcellular distribution of organic solutes. J. Exp. Bot. 49:1361-1370.

Carrow R.N. 1996. Drought avoidance characteristics of diverse tall fescue cultivars. Crop Sci. 36:371-377.

Chaves, M.M., J.P. Maroco, and J.S. Pereira. 2003. Understanding plant responses to drought-from genes to the whole plant. Functional Plant Biol. 30:239-264.

Crowe, J.H., F.A. Hoekstra, and L.M. Crowe. 1992. Anhydrobiosis. Annu. Rev. Physiol. 54:579-599.

DaCosta, M. and B. Huang. 2006. Minimum water requirements for creeping, colonial, and velvet bentgrasses under fairway conditions. Crop Sci. 46:81-89.

Elmi,A.A. and C.P. West. 1995. Endophyte infection effects on stomatal conductance, osmotic adjustment and drought recovery of tall fescue. New Phytol. 131:61-67.

Geerts, P., A. Buldgen, T. Diallo, and A. Dieng. 1998. Drought resistance by six Senegalese local strains of Andropogon gayanus var. bisquamulatus through osmoregulation. Trop. Grasslands 32:235-242.

Hare, P.D., W.A. Cress, and J. Van Staden. 1998. Dissecting the roles of osmolyte accumulation during stress. Plant Cell Environ. 21:535-553.

Hoagland, D.R. and D.I. Arnon. 1950. The water-culture method for growing plants without soil, p. 31. Calif. Agr. Expt. Sta. Circ. 347. Univ. of California, Berkeley.

Hoekstra, F.A., E.A. Golovina, and J. Buitink. 2001. Mechanisms of plant desiccation tolerance. Trends Plant Sci. 6:431-438.

Ingram, J. and D. Bartels. 1996. The molecular basis of dehydration tolerance in plants. Annu. Rev. Plant Physiol. Plant Mol. Biol. 47:377-403.

Jiang, Y. and B. Huang. 2001. Osmotic adjustment and root growth associated with drought preconditioning-enhanced heat tolerance in Kentucky bluegrass. Crop Sci. 41:1168-1173.

Jones, M.M., C.B. Osmond, and N.C. Turner. 1980. Accumulation of solutes in leaves of sorghum and sunflower in response to water deficit. Aust. J. Plant Physiol. 7:193-205.

Lacerda, C.F., J. Cambraia, M.A. Oliva, H.A. Ruiz, and J.T. Prisco. 2003. Solute accumulation and distribution during shoot and leaf development in two sorghum genotypes under salt stress. Environ. Exp. Bot. 49:107-120.

Lerner, H.R., D. Bem-Bassat, L. Reinhold, and A. Poljakoff-Mayber. 1978. Induction of 'pore' formation in plant cell membranes by toluene. Plant Physiol. 61:213-217.

Maggio, A., R.A. Bressan, P.M. Hasegawa, and R.D. Locy. 1997. Moderately increased constituitive proline does not alter osmotic stress tolerance. Physiol. Plant. 101:240-246.

Marcum, K.B. and C.L. Murdoch. 1994. Salinity tolerance mechanisms of six $C_{4}$ turfgrasses. J. Amer. Soc. Hort. Sci. 119:779-784.

Morgan, J.M. 1983. Osmoregulation as a selection criterion for drought tolerance in wheat. Aust. J. Agric. Res. 34:607-614.

Morgan, J.M. 1992. Osmotic components and properties associated with genotypic differences in osmoregulation in wheat. Aust. J. Plant Physiol. 6:67-76.

Nguyen-Queyrens, A. and F. Bouchet-Lannat. 2003. Osmotic adjustment in three-year-old seedlings of five provenances of maritime pine (Pinus pinaster) in response to drought. Tree Physiol. 23:397-404.

Premachandra, G.S., H. Saneoka, K. Fujita, and S. Ogata. 1992. Osmotic adjustment and stomatal response to water deficits in maize. J. Expt. Bot. 43:1451-1456.

Premachandra, G.S., D.T. Hahn, D. Rhodes, and R.J. Joly. 1995. Leaf water relations and solute accumulation in two grain sorghum lines exhibiting contrasting drought tolerance. J. Exp. Bot. 46:1833-1841.

Qian, Y. and J.D. Fry. 1997. Water relations and drought tolerance of four turfgrasses. J. Amer. Soc. Hort. Sci. 122:129-133.

Qian, Y., J.D. Fry, and W.S. Upham. 1997. Rooting and drought avoidance of warm-season turfgrasses and tall fescue in Kansas. Crop Sci. 37:905-910. 
Rhodes, D. and A.D. Hanson. 1993. Quaternary ammonium and tertiary sulfonium compounds in higher plants. Annu. Rev. Plant Physiol. Plant Mol. Biol. 44:357-384.

Richardson, M.D., G.W. Chapman, C.S. Hoveland, and C.W. Bacon. 1992. Sugar alcohols in endophyte-infected tall fescue under drought. Crop Sci. 32:1060-1061.

Thomas, H. 1986. Effect of rate of dehydration on leaf water status and osmotic adjustment in Dactylis glomerata L., Lolium perenne L. and L. multiflorum Lam. Ann. Bot. (London) 57:225-235.

Thomas, H. 1991. Accumulation and consumption of solutes in swards of Lolium perenne during drought and after rewatering. New Phytol. 118:35-48.

Toft, N.L., S.J. McNaughton, and N.J. Georgiadis. 1987. Effects of water stress and simulated grazing on leaf elongation and water relation of an East African grass, Eustachys paspaloides. Aust. J. Plant Physiol. $14: 211-226$.

Topp, G.C., J.L. Davis, and A.P. Annan. 1980. Electromagnetic determination of soil water content: Measurements in coaxial transmission lines. Water Resources Res. 16:574-582.

White, R.H., M.C.Engelke, S.J. Morton, and B.A. Ruemmele. 1992.Competitive turgor maintenance in tall fescue. Crop Sci. 32:251-256.

Wilson, J.R. and M.M. Ludlow. 1983. Time trends for change in osmotic adjustment and water relations of leaves of Cenchrus ciliaris during and after water stress. Aust. J. Plant Physiol. 10:15-24.

Zhang, J., H.T. Nguyen, and A. Blum. 1999. Genetic analysis of osmotic adjustment in crop plants. J. Expt. Bot. 50:291-302. 